\title{
Meta-Analysis of Risk Factors for Lower Extremity Amputation in Diabetes Mellitus Patients with Foot Ulcers
}

\author{
Anissa Eka Septiani' ${ }^{1)}$, Setyo Sri Rahardjo²), Hanung Prasetya3) \\ ${ }^{1)}$ Masters Program in Public Health, Universitas Sebelas Maret \\ 2)Faculty of Medicine, Universitas Sebelas Maret \\ 3)Study Program of Acupuncture, School of Health Polytechnics, \\ Ministry of Health, Surakarta
}

\section{ABSTRACT}

Background: Diabetic foot ulcer is a complication of diabetes mellitus which costs high, takes long wound care, increases mortality, morbidity and causes non-traumatic amputation. There are risk factors that are thought to be the cause of lower limb amputation in diabetic foot ulcers, namely peripheral artery disease, hypertension and gender. This study aims to estimate the influence of peripheral artery disease, hypertension and gender on the risk of lower limb amputation in diabetes mellitus patients with leg ulcers.

Subjects and Method: Meta-analysis studies and systematic reviews were applied to this study using electronic databases of Pubmed, Scopus, Google Scholar, and Springer Link. The keywords to search for articles are as follows: "diabetic foot", "lower limb amputation", "lower extremity amputation", "risk factor", "predictor", "cohort", "retrospective", "adjusted odds ratio". Articles were collected using PRISMA diagrams, and analyzed using the Review Manager 5.3 application.

Results: Meta-analysis of 9 cohort articles of diabetic foot ulcer patients with peripheral artery disease $(\mathrm{aOR}=2.46 ; 95 \% \mathrm{CI}=1.70-3.55$; $\mathrm{p}<0.01)$; Meta-analysis of 8 cohort articles, diabetic foot ulcer patients with hypertension $(\mathrm{aOR}=1.05 ; 95 \% \mathrm{CI}=0.66-1.68 ; \mathrm{p}=0.83)$; Meta-analysis of 9 cohort articles of male diabetic foot ulcer patients $(\mathrm{aOR}=1.60 ; 95 \%$ $\mathrm{CI}=1.32-1.94 ; \mathrm{p}<0.01) ;$ Peripheral artery disease, hypertension and male gender are risk factors that can increase the incidence of lower limb amputation.

Conclusion: Peripheral artery disease, hypertension and male gender are risk factors that can increase the incidence of lower limb amputation.

Keywords: Peripheral artery disease, diabetic foot ulcer, lower limb amputation

\section{Correspondence:}

Anissa Eka Septiani. Masters Program in Public Health. Universitas Sebelas Maret. Jl. Ir. Sutami 36A, Surakarta 57126, Central Java,. Email: sanissaeka@gmail.com. Mobile: o89514646458.

Cite this as:

Septiani AE, Rahardjo SS, Prasetya H (2020). Meta-Analysis of Risk Factors for Lower Extremity Amputation in Diabetes Mellitus Patients with Foot Ulcers. Indones J Med. 05(04): 343-355. https://doi.org/10.26911/theijmed.2020.05.04.10.

cc) (i) (-) Indonesian Journal of Medicine is licensed under a Creative Commons (c) Ar No SA Attribution-NonCommercial-ShareAlike 4.0 International License.

\section{BACKGROUND}

Non-communicable diseases (NCD) kill 41 million people each year, equivalent to $71 \%$ of all deaths globally, one of which is diabetes mellitus which is responsible for the death of 1.6 million people each year (WHO, 2020). Patients with diabetes mellitus are prone to complications, one of the complications that arise is diabetic foot ulcers, with an incidence risk of $10 \%-25 \%$ of all patients. Diabetic foot ulcers are one of the health problems that cost a lot, take long wound care in the hospital and at home, increase the risk of mortality and 
morbidity and are the main cause of nontraumatic amputation of the lower extremities (Sayiner et al., 2018).

The occurrence of lower limb amputation in diabetic foot ulcers is triggered by several risk factors. The main independent risk factors for amputation from multivariate analytic studies were long duration of diabetes, peripheral neuropathy, peripheral artery disease (PAP), high levels of HbA1c or fasting plasma glucose, history of leg ulcers or amputations, retinopathy, hypertension and gender (Krittiyawong et al. al., 2006).

\section{SUBJECTS AND METHOD}

\section{Study Design}

This was systematic review and meta-analysis. This research will be carried out by searching and selecting articles conducted around the world. The articles used were published in the period 2000 - 2020. The articles used in this study came from electronic data bases in the form of: Pubmed, Google Scholar, Springer Link and Scopus. The keywords used in the article search were as follows: "diabetic foot", "lower limb amputation", "lower extremity amputation", "risk factor", "predictor", "cohort", "retrospective", "adjusted odds ratio" .

\section{Inclusion Criteria}

The classification of the inclusion criteria in this study is a full-text article with an observational study (cohort). The selected article discussed the risk factors for lower limb amputation in diabetes mellitus sufferers with foot ulcers. Articles are published in Indonesian and English. The research data were multivariate.

\section{Exclusion Criteria}

The classification of the exclusion criteria in this study was the study conducted with
RCT, quasi-experimental, and study protocol. Articles are those published in languages other than Indonesian and English.

\section{Operational Definition of Variables} Lower limb amputation is the removal or cutting of part or all of a limb by cutting the bone or precisely the joint of the lower limb.

Peripheral artery disease is a condition in which blood flow to the legs becomes blocked due to narrowing of the blood vessels that originate from the heart (arteries).

Hypertension is an abnormal increase in blood pressure in arterial blood vessels with a systolic blood pressure measurement of more than $\geq 140 \mathrm{mmHg}$, and or diastolic blood pressure $\geq 90 \mathrm{mmHg}$ on two measurements with an interval of 5 minutes in a well-rested state.

Gender is a biological and anatomical division of gender which is expressed in terms of male and female.

\section{Data Analysis}

Data processing was carried out using the Review Manager (RevMan 5.3) measured by the effect size and heterogeneity to determine the research merging model and forming the meta-analysis results in the form of a forest plot and the possibility of bias being presented with a funnel plot

\section{RESULTS}

The process of searching and selecting articles through 4 databases can be seen in Figure 1.

Figure 2. shows an overview of the research areas used in this meta-analysis which are spread across 4 continents, namely the Americas, Africa, Asia, and Europe. 
Septiani et al./ Risk Factors for Lower Extremity Amputation

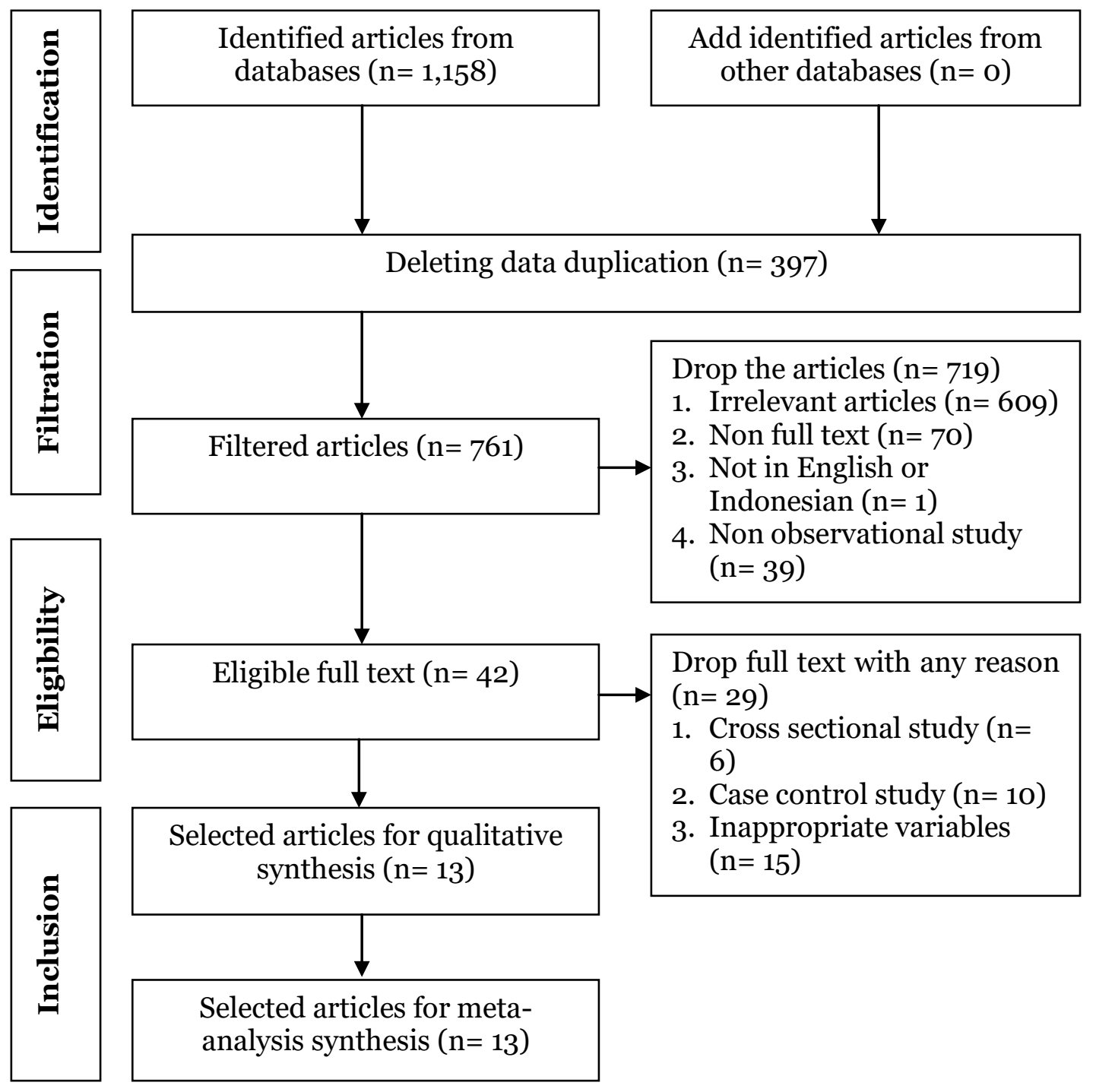

Figure 1. Flowchart of the review process

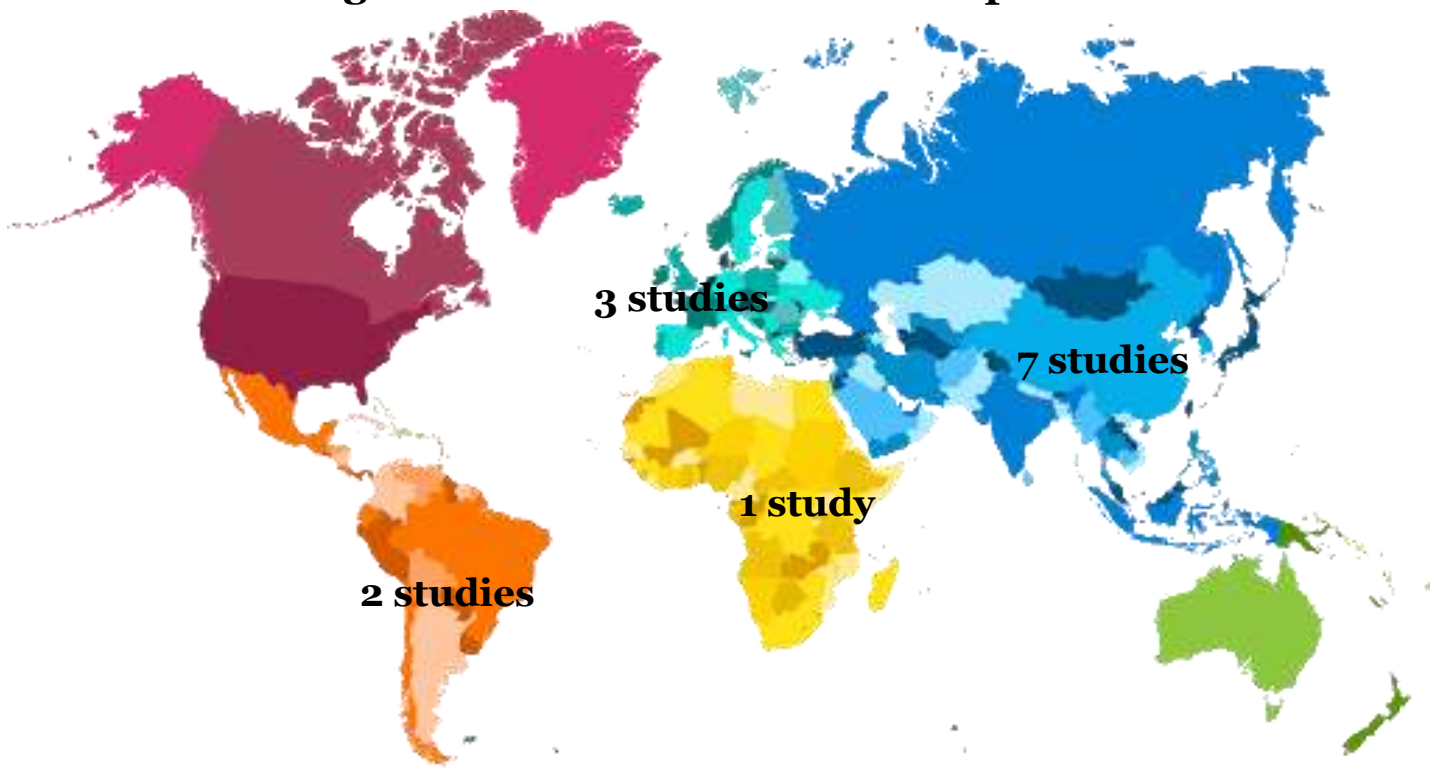

Figure 2. Overview of the research area (Vexels, 2014) 


\section{Peripheral artery disease}

There are 9 cohort articles as a research source for meta-analysis of peripheral artery disease as a risk factor for lower limb amputation in diabetes mellitus sufferers with leg ulcers. The description of each study can be seen in Table 1 .

\section{a. Forest plot}

Based on Figure 3, it can be seen that peripheral artery disease can increase the incidence of lower limb amputation in diabetic foot ulcer patients by 2.46 times compared to those without PAP, as well as statistically significant (p <0.01). heterogeneity of research data shows I2 = $60 \%$ so that the distribution of data is declared heterogeneous (Random effect model).

\section{b. Funnel plot}

Based on Figure 4, it can be seen that the plots on the right and left are not symmetrical with each other, the left side has 5 plots while the right side has 4 plots. The left plot has a standard error of 0.7 while the plot on the right has a standard error of 0.6 . This indicates that there is a publication bias in the study.

Table 1.Primary research sources of meta-analysis on peripheral artery disease of lower limb amputations in patients with diabetic foot ulcers

\begin{tabular}{|c|c|c|c|c|c|}
\hline $\begin{array}{c}\text { Author } \\
\text { (Year) }\end{array}$ & Location & $\begin{array}{c}\text { Sample } \\
\text { Size }\end{array}$ & $\begin{array}{c}\text { Population } \\
(\mathbf{P})\end{array}$ & $\begin{array}{c}\text { Intervent (I) and } \\
\text { Comparison (C) }\end{array}$ & Outcome \\
\hline $\begin{array}{l}\text { Acar \& Kacira } \\
(2017)\end{array}$ & Turkey & 132 & $\begin{array}{l}\text { Patients with } \\
\text { diabetic foot } \\
\text { ulcers }\end{array}$ & $\begin{array}{l}\text { I: PAP } \\
\text { C: No PAP }\end{array}$ & $\begin{array}{l}\text { Lower limb } \\
\text { amputation }\end{array}$ \\
\hline $\begin{array}{l}\text { Beaney et al., } \\
(2016)\end{array}$ & The UK & 165 & $\begin{array}{l}\text { Patients with } \\
\text { diabetic foot } \\
\text { ulcers }\end{array}$ & $\begin{array}{l}\text { I: PAP } \\
\text { C: No PAP }\end{array}$ & $\begin{array}{l}\text { Lower limb } \\
\text { amputation }\end{array}$ \\
\hline $\begin{array}{l}\text { Costa et al., } \\
(2017)\end{array}$ & Brazil & 654 & $\begin{array}{l}\text { Patients with } \\
\text { diabetic foot } \\
\text { ulcers }\end{array}$ & $\begin{array}{l}\text { I: PAP } \\
\text { C: No PAP }\end{array}$ & $\begin{array}{l}\text { Lower limb } \\
\text { amputation }\end{array}$ \\
\hline $\begin{array}{l}\text { Ferrira et al., } \\
(2018)\end{array}$ & Portugal & 631 & $\begin{array}{l}\text { Patients with } \\
\text { diabetic foot } \\
\text { ulcers }\end{array}$ & $\begin{array}{l}\text { I: PAP } \\
\text { C: No PAP }\end{array}$ & $\begin{array}{l}\text { Lower limb } \\
\text { amputation }\end{array}$ \\
\hline $\begin{array}{l}\text { Jeon et al., } \\
(2016)\end{array}$ & $\begin{array}{l}\text { South } \\
\text { Korea }\end{array}$ & 158 & $\begin{array}{l}\text { Patients with } \\
\text { diabetic foot } \\
\text { ulcers }\end{array}$ & $\begin{array}{l}\text { I: PAP } \\
\text { C: No PAP }\end{array}$ & $\begin{array}{l}\text { Lower limb } \\
\text { amputation }\end{array}$ \\
\hline $\begin{array}{l}\text { Jeong et al., } \\
\text { (2017) }\end{array}$ & $\begin{array}{l}\text { South } \\
\text { Korea }\end{array}$ & 380 & $\begin{array}{l}\text { Patients with } \\
\text { diabetic foot } \\
\text { ulcers }\end{array}$ & $\begin{array}{l}\text { I: PAP } \\
\text { C: No PAP }\end{array}$ & $\begin{array}{l}\text { Lower limb } \\
\text { amputation }\end{array}$ \\
\hline $\begin{array}{l}\text { Kim et al., } \\
(2018)\end{array}$ & $\begin{array}{l}\text { South } \\
\text { Korea }\end{array}$ & 141 & $\begin{array}{l}\text { Patients with } \\
\text { diabetic foot } \\
\text { ulcers }\end{array}$ & $\begin{array}{l}\text { I: PAP } \\
\text { C: No PAP }\end{array}$ & $\begin{array}{l}\text { Lower limb } \\
\text { amputation }\end{array}$ \\
\hline $\begin{array}{l}\text { Sayiner et al., } \\
\text { (2018) }\end{array}$ & Turkey & 400 & $\begin{array}{l}\text { Patients with } \\
\text { diabetic foot } \\
\text { ulcers }\end{array}$ & $\begin{array}{l}\text { I: PAP } \\
\text { C: No PAP }\end{array}$ & $\begin{array}{l}\text { Lower limb } \\
\text { amputation }\end{array}$ \\
\hline $\begin{array}{l}\text { Vanbattum et } \\
\text { al., (2011) }\end{array}$ & Netherland & 1,232 & $\begin{array}{l}\text { Patients with } \\
\text { diabetic foot } \\
\text { ulcers }\end{array}$ & $\begin{array}{l}\text { I: PAP } \\
\text { C: No PAP }\end{array}$ & $\begin{array}{l}\text { Lower limb } \\
\text { amputation }\end{array}$ \\
\hline
\end{tabular}


Septiani et al./ Risk Factors for Lower Extremity Amputation

\begin{tabular}{|c|c|c|c|c|c|c|c|c|c|}
\hline Study or Subgroup & log[Odds Ratio] & SE & Weight & $\begin{array}{c}\text { Odds Ratio } \\
\text { IV, Random, } 95 \% \mathrm{Cl}\end{array}$ & & $\begin{array}{r}\text { Odds I } \\
\text { IN, Randor }\end{array}$ & $\begin{array}{l}\text { Ratio } \\
\mathrm{m}, 95 \% \mathrm{Cl}\end{array}$ & & \\
\hline Acar dan Kacira 2017 & 0.8065 & 0.4218 & $10.4 \%$ & $2.24[0.98,5.12]$ & & & & & \\
\hline Beaney et al., 2016 & -0.1165 & 0.4762 & $9.1 \%$ & $0.89[0.35,2.26]$ & & & & & \\
\hline Costa et al., 2017 & 0.6103 & 0.2256 & $16.5 \%$ & $1.84[1.18,2.86]$ & & & $\rightarrow-$ & & \\
\hline Ferrira et al., 2018 & 1.2556 & 0.5107 & $8.3 \%$ & $3.51[1.29,9.55]$ & & & & & \\
\hline Jeon et al., 2016 & 2.205 & 0.4332 & $10.1 \%$ & $9.07[3.88,21.20]$ & & & & & \\
\hline Jeong et al., 2017 & 1.4793 & 0.6093 & $6.6 \%$ & $4.39[1.33,14.49]$ & & & & & \\
\hline Kim et al., 2018 & 0.3031 & 0.7408 & $5.0 \%$ & $1.35[0.32,5.78]$ & & & & & \\
\hline Sayiner et al., 2018 & 1.0913 & 0.2407 & $16.0 \%$ & $2.98[1.86,4.77]$ & & & $\rightarrow-$ & & \\
\hline Vanbattum et al., 2011 & 0.6098 & 0.1772 & $18.1 \%$ & $1.84[1.30,2.60]$ & & & $\rightarrow$ & & \\
\hline Total $(95 \% \mathrm{Cl})$ & & & $100.0 \%$ & $2.46[1.70,3.55]$ & & & & & \\
\hline \multicolumn{5}{|c|}{$\begin{array}{l}\text { Heterogeneity: } \mathrm{Tau}^{2}=0.16 ; \mathrm{Chi}^{2}=20.01, \mathrm{df}=8(\mathrm{P}=0.01) ; \mathrm{I}^{2}=60 \% \\
\text { Test for overall effect: } Z=4.77(\mathrm{P}=0.00001)\end{array}$} & 0.01 & $0.1{ }^{1}{ }^{1}$ & PAD & 10 & 100 \\
\hline
\end{tabular}

Figure 3. Forest plot meta-analysis of PAD correlation with lower extremity amputation on diabetic foot ulcer

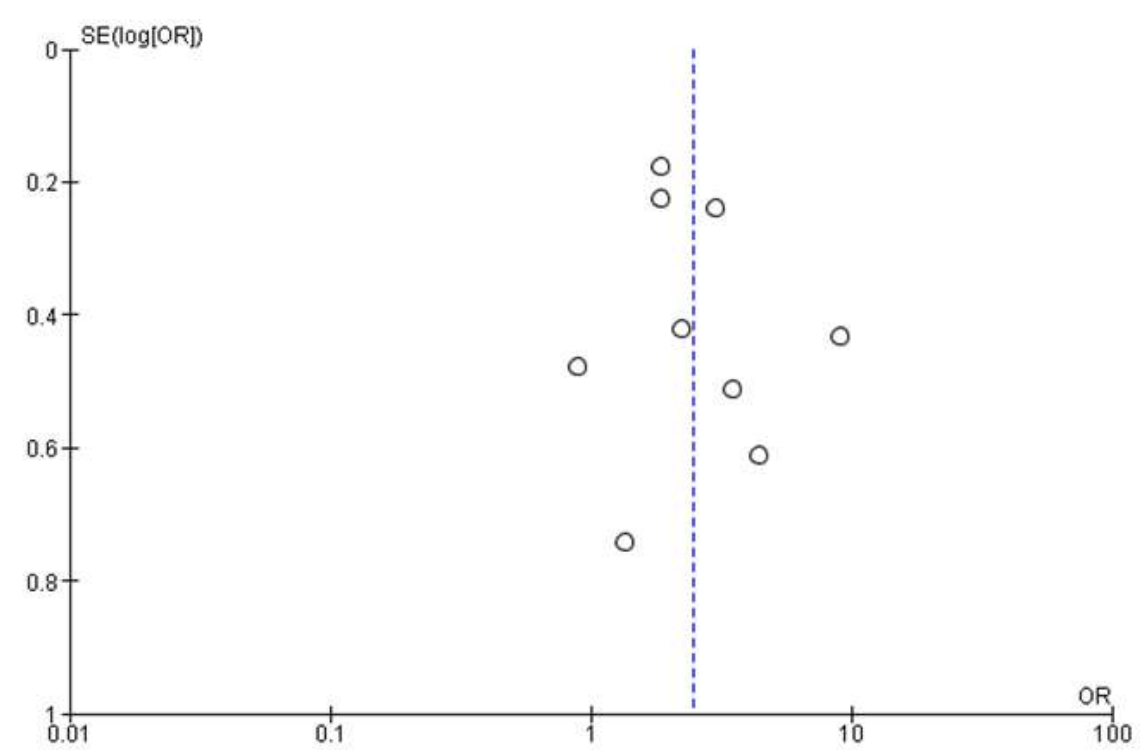

Figure 4. Funnel plot meta-analysis of PAD correlation with lower extremity amputation on diabetic foot ulcer

\section{Hypertension}

There are 8 cohort articles as a source of meta-analysis of hypertension as a risk factor for lower limb amputation in DM patients with foot ulcers. An overview of each study can be seen in Table 2 .

\section{a. Forest plot}

Based on Figure 5, it is known that hypertension can increase the incidence of lower limb amputation in diabetic foot ulcer patients by 1.05 times compared to normal blood pressure, but it is not statistically significant $(p=0.83)$. Heterogeneity of research data shows $\mathrm{I}^{2}=71 \%$ so that the distribution of the data is heterogeneous (Random effect model).

\section{b. Funnel plot}

Based on Figure 6, it can be seen that the plots on the right and left are not symmetrical with each other, the left side has 4 plots while the right side has 3 plots. The left plot has a standard error of 1 while the right side plot has a standard error of 0.5. In addition, there is 1 plot on the left side that is away from the vertical center line. 
This indicates that there is a publication

bias in the study.

Table 2. Primary research sources of meta-analysis on hypertension of lower limb amputations in patients with diabetic foot ulcers

\begin{tabular}{|c|c|c|c|c|c|}
\hline $\begin{array}{l}\text { Author, } \\
\text { (Year) }\end{array}$ & Location & $\begin{array}{l}\text { Sample } \\
\text { Size }\end{array}$ & Population (P) & $\begin{array}{l}\text { Intervention (I) and } \\
\text { Comparison (C) }\end{array}$ & Outcome \\
\hline $\begin{array}{l}\text { Acar dan } \\
\text { Kacira } \\
(2017)\end{array}$ & Turkey & 132 & $\begin{array}{l}\text { Patients with } \\
\text { diabetic foot ulcers }\end{array}$ & $\begin{array}{l}\text { I: Hypertension } \\
\text { C: Normal }\end{array}$ & $\begin{array}{l}\text { Lower limb } \\
\text { amputation }\end{array}$ \\
\hline $\begin{array}{l}\text { Beaney et } \\
\text { al., (2016) }\end{array}$ & English & 165 & $\begin{array}{l}\text { Patients with } \\
\text { diabetic foot ulcers }\end{array}$ & $\begin{array}{l}\text { I: Hypertension } \\
\text { C: Normal }\end{array}$ & $\begin{array}{l}\text { Lower limb } \\
\text { amputation }\end{array}$ \\
\hline $\begin{array}{l}\text { Costa et } \\
\text { al., (2017) }\end{array}$ & Brazil & 654 & $\begin{array}{l}\text { Patients with } \\
\text { diabetic foot ulcers }\end{array}$ & $\begin{array}{l}\text { I: Hypertension } \\
\text { C: Normal }\end{array}$ & $\begin{array}{l}\text { Lower limb } \\
\text { amputation }\end{array}$ \\
\hline $\begin{array}{l}\text { Jeon et al., } \\
(2016)\end{array}$ & $\begin{array}{l}\text { South } \\
\text { Korea }\end{array}$ & 158 & $\begin{array}{l}\text { Patients with } \\
\text { diabetic foot ulcers }\end{array}$ & $\begin{array}{l}\text { I: Hypertension } \\
\text { C: Normal }\end{array}$ & $\begin{array}{l}\text { Lower limb } \\
\text { amputation }\end{array}$ \\
\hline $\begin{array}{l}\text { Jeong et } \\
\text { al., (2017) }\end{array}$ & $\begin{array}{l}\text { South } \\
\text { Korea }\end{array}$ & 380 & $\begin{array}{l}\text { Patients with } \\
\text { diabetic foot ulcers }\end{array}$ & $\begin{array}{l}\text { I: Hypertension } \\
\text { C: Normal }\end{array}$ & $\begin{array}{l}\text { Lower limb } \\
\text { amputation }\end{array}$ \\
\hline $\begin{array}{l}\text { Kim et al., } \\
(2018)\end{array}$ & $\begin{array}{l}\text { South } \\
\text { Korea }\end{array}$ & 141 & $\begin{array}{l}\text { Patients with } \\
\text { diabetic foot ulcers }\end{array}$ & $\begin{array}{l}\text { I: Hypertension } \\
\text { C: Normal }\end{array}$ & $\begin{array}{l}\text { Lower limb } \\
\text { amputation }\end{array}$ \\
\hline $\begin{array}{l}\text { Sayiner et } \\
\text { al., (2018) }\end{array}$ & Turkey & 400 & $\begin{array}{l}\text { Patients with } \\
\text { diabetic foot ulcers }\end{array}$ & $\begin{array}{l}\text { I: Hypertension } \\
\text { C: Normal }\end{array}$ & $\begin{array}{l}\text { Lower limb } \\
\text { amputation }\end{array}$ \\
\hline $\begin{array}{l}\text { Yesil et al., } \\
\text { (2009) }\end{array}$ & Turkey & 670 & $\begin{array}{l}\text { Patients with } \\
\text { diabetic foot ulcers }\end{array}$ & $\begin{array}{l}\text { I: Hypertension } \\
\text { C: Normal }\end{array}$ & $\begin{array}{l}\text { Lower limb } \\
\text { amputation }\end{array}$ \\
\hline
\end{tabular}

\begin{tabular}{|c|c|c|c|c|c|c|c|c|}
\hline Study or Subgroup & log[Odds Ratio] & SE & Weight & $\begin{array}{c}\text { Odds Ratio } \\
\mathrm{N} \text {, Random, } 95 \% \mathrm{Cl}\end{array}$ & & $\begin{aligned} \text { Odds } \\
\text { N, Randor }\end{aligned}$ & $\begin{array}{l}\text { Ratio } \\
\mathrm{m}, 95 \% \mathrm{Cl}\end{array}$ & \\
\hline Acar dan Kacira 2017 & 0.9002 & 0.5245 & $10.6 \%$ & $2.46[0.88,6.88]$ & & & & \\
\hline Beaney et al., 2016 & -2.551 & 1.048 & $4.2 \%$ & $0.08[0.01,0.61]$ & & & & \\
\hline Costa et al., 2017 & -0.405 & 0.2065 & $18.7 \%$ & $0.67[0.44,1.00]$ & & $\rightarrow-$ & & \\
\hline Jeon et al, 2016 & 1.1474 & 0.4248 & $12.8 \%$ & $3.15[1,37,7,24]$ & & & & \\
\hline Jeong et al., 2017 & .0 .5621 & 0.5881 & $9.3 \%$ & $0.57[0.18,1.80]$ & & & & \\
\hline Kim et al., 2018 & -0.4401 & 0.701 & $7.5 \%$ & $0.64[0.16,2.54]$ & & & & \\
\hline Sayiner et al, 2018 & 0.1071 & 0.2544 & $17.4 \%$ & $1.11[0.68,1.83]$ & & & & \\
\hline Yesil et al., 2009 & 0.2904 & 0.1733 & $19.5 \%$ & $1.34[0.95,1.88]$ & & & & \\
\hline Total $(95 \% \mathrm{Cl})$ & & & $100.0 \%$ & $1.05[0.66,1.68]$ & & & & \\
\hline \multicolumn{5}{|c|}{$\begin{array}{l}\text { Heterogeneity: } \mathrm{Tau}^{2}=0.26 ; \mathrm{Chi}^{2}=23.80, \mathrm{df}=7(P=0.001) ; \mathrm{I}^{2}=71 \% \\
\text { Test for overall effect } Z=0.21(P=0.83)\end{array}$} & 0.01 & $\begin{array}{l}0.1 \\
\text { Tensi }\end{array}$ & & 10 \\
\hline
\end{tabular}

Figure 5. Forest plot meta-analysis of correlation of hypertension and lower extremity amputation on diabetic foot ulcer

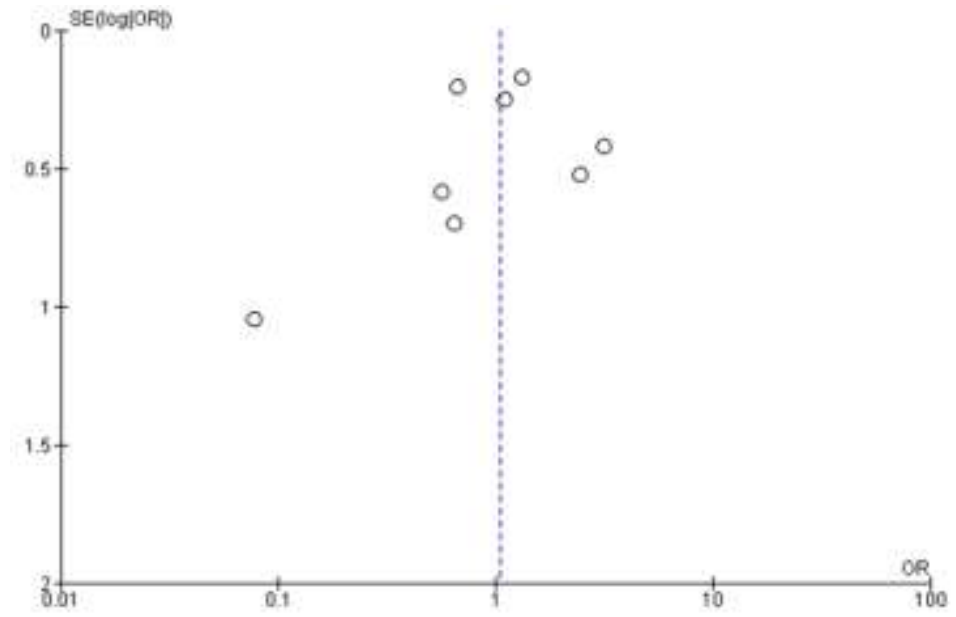

Figure 6. Funnel plot meta-analysis of correlation of hypertension and lower extremity amputation on diabetic foot ulcer 


\section{Gender}

There were 9 cohort articles as a source of meta-analysis of gender as a risk factor for lower limb amputation in DM patients with foot ulcers. An overview of each study can be seen in Table 3 .

\section{a. Forest plot}

Based on Figure 7, it can be seen that male gender can increase the incidence of lower limb amputation in diabetic foot ulcer patients by 1.60 times compared to female sex, this is statistically significant $(\mathrm{p}<0.01)$. homogeneity of research data shows $\mathrm{I}^{2}=$
$47 \%$ so that the distribution of data is homogeneous (Fixed effect model).

\section{b. Funnel plot}

Based on Figure 8, it can be seen that the plots on the right and left look symmetrical to each other, the left side has 4 plots while the right side has 4 plots but there is 1 plot on the right away from the vertical line and there is 1 plot offending the vertical line which has a standard error 1 . The left plot has a SE of 0 - 0.5 while the plot on the right has a SE of $\mathrm{O}-1$. This indicates that there is a publication bias in the study.

\begin{tabular}{|c|c|c|c|c|c|c|c|c|}
\hline Study or Subgroup & log[Odds Ratio] & SE & Weight & $\begin{array}{l}\text { Odds Ratio } \\
\text { N, Fixed, } 95 \% \mathrm{Cl}\end{array}$ & \multicolumn{4}{|c|}{$\begin{array}{c}\text { Odds Ratio } \\
\text { N, Fixed, } 95 \% \mathrm{Cl}\end{array}$} \\
\hline Acar dan Kacira 2017 & 1.6332 & 0.6064 & $2.7 \%$ & $5.12[1.56,16.81]$ & & & & \\
\hline Bekele et al., 2020 & 0.5068 & 1.1392 & $0.8 \%$ & $1.66[0.18,15.48]$ & & & & \\
\hline Jeon et al., 2016 & 0.1655 & 0.3451 & $8.2 \%$ & $1.18[0.60,2.32]$ & & & & \\
\hline Kim et al., 2018 & 0.802 & 0.7096 & $1.9 \%$ & $2.23[0.55,8.96]$ & & & & \\
\hline Moon et al., 2019 & 2.1061 & 0.8924 & $1.2 \%$ & $8.22[1.43,47.24]$ & & & & \\
\hline Mouraneto et al., 2012 & 1.2355 & 0.3276 & $9.1 \%$ & $3.44[1.81,6.54]$ & & & & \\
\hline Sayiner et al., 2018 & 0.2897 & 0.2553 & $15.0 \%$ & $1.34[0.81,2.20]$ & & & & \\
\hline Vanbattum et al., 2011 & 0.3507 & 0.184 & $29.0 \%$ & $1.42[0.99,2.04]$ & & & & \\
\hline Yesil et al., 2009 & 0.34 & 0.1749 & $32.0 \%$ & $1.40[1.00,1.98]$ & & & & \\
\hline Total $(95 \% \mathrm{Cl})$ & & & $100.0 \%$ & $1.60[1.32,1.94]$ & & & & \\
\hline \multicolumn{4}{|c|}{$\begin{array}{l}\text { Heterogeneity: } C h i^{2}=14.97, d f=8(P=0.06) ; I^{2}=47 \% \\
\text { Test for overall effect: } Z=4.74(P<0.00001)\end{array}$} & & 0.02 & \multicolumn{2}{|r|}{10} & 50 \\
\hline
\end{tabular}

\section{Figure 7. Forest plot meta-analysis of gender relations with amputation of the lower limb in diabetic foot ulcers}

Table 3. Primary research sources of gender meta-analysis of lower limb amputations in patients with diabetic foot ulcers

\begin{tabular}{|c|c|c|c|c|c|}
\hline $\begin{array}{l}\text { Author } \\
\text { (Year) }\end{array}$ & Location & $\begin{array}{c}\text { Sample } \\
\text { Size }\end{array}$ & Population (P) & $\begin{array}{l}\text { Intervention (I) } \\
\text { and Comparison } \\
\text { (C) }\end{array}$ & Outcome \\
\hline $\begin{array}{l}\text { Acar dan } \\
\text { Kacira (2017) }\end{array}$ & Turkey & 132 & $\begin{array}{l}\text { Patients with } \\
\text { diabetic foot ulcers }\end{array}$ & $\begin{array}{l}\text { I: Hypertension } \\
\text { C: Normal }\end{array}$ & $\begin{array}{l}\text { Lower limb } \\
\text { amputation }\end{array}$ \\
\hline $\begin{array}{l}\text { Bekele et al., } \\
(2020)\end{array}$ & Ethiopia & 115 & $\begin{array}{l}\text { Patients with } \\
\text { diabetic foot ulcers }\end{array}$ & $\begin{array}{l}\text { I: Hypertension } \\
\text { C: Normal }\end{array}$ & $\begin{array}{l}\text { Lower limb } \\
\text { amputation }\end{array}$ \\
\hline $\begin{array}{l}\text { Jeon et al., } \\
(2016)\end{array}$ & $\begin{array}{l}\text { South } \\
\text { Korea }\end{array}$ & 158 & $\begin{array}{l}\text { Patients with } \\
\text { diabetic foot ulcers }\end{array}$ & $\begin{array}{l}\text { I: Hypertension } \\
\text { C: Normal }\end{array}$ & $\begin{array}{l}\text { Lower limb } \\
\text { amputation }\end{array}$ \\
\hline $\begin{array}{l}\text { Jeong et al., } \\
(2017)\end{array}$ & $\begin{array}{l}\text { South } \\
\text { Korea }\end{array}$ & 380 & $\begin{array}{l}\text { Patients with } \\
\text { diabetic foot ulcers }\end{array}$ & $\begin{array}{l}\text { I: Hypertension } \\
\text { C: Normal }\end{array}$ & $\begin{array}{l}\text { Lower limb } \\
\text { amputation }\end{array}$ \\
\hline $\begin{array}{l}\text { Kim et al., } \\
(2018)\end{array}$ & $\begin{array}{l}\text { South } \\
\text { Korea }\end{array}$ & 141 & $\begin{array}{l}\text { Patients with } \\
\text { diabetic foot ulcers }\end{array}$ & $\begin{array}{l}\text { I: Hypertension } \\
\text { C: Normal }\end{array}$ & $\begin{array}{l}\text { Lower limb } \\
\text { amputation }\end{array}$ \\
\hline $\begin{array}{l}\text { Moon et al., } \\
\text { (2019) }\end{array}$ & $\begin{array}{l}\text { South } \\
\text { Korea }\end{array}$ & 1792 & $\begin{array}{l}\text { Patients with } \\
\text { diabetic foot ulcers }\end{array}$ & $\begin{array}{l}\text { I: Hypertension } \\
\text { C: Normal }\end{array}$ & $\begin{array}{l}\text { Lower limb } \\
\text { amputation }\end{array}$ \\
\hline $\begin{array}{l}\text { Sayiner et al., } \\
\text { (2018) }\end{array}$ & Turkey & 400 & $\begin{array}{l}\text { Patients with } \\
\text { diabetic foot ulcers }\end{array}$ & $\begin{array}{l}\text { I: Hypertension } \\
\text { C: Normal }\end{array}$ & $\begin{array}{l}\text { Lower limb } \\
\text { amputation }\end{array}$ \\
\hline $\begin{array}{l}\text { Moureneto et } \\
\text { al., (2012) }\end{array}$ & Brazil & 496 & $\begin{array}{l}\text { Patients with } \\
\text { diabetic foot ulcers }\end{array}$ & $\begin{array}{l}\text { I: Hypertension } \\
\text { C: Normal }\end{array}$ & $\begin{array}{l}\text { Lower llimb } \\
\text { amputation }\end{array}$ \\
\hline $\begin{array}{l}\text { Yesil et al., } \\
\text { (2009) }\end{array}$ & Turkey & 670 & $\begin{array}{l}\text { Patients with } \\
\text { diabetic foot ulcers }\end{array}$ & $\begin{array}{l}\text { I: Hypertension } \\
\text { C: Normal }\end{array}$ & $\begin{array}{l}\text { Lower limb } \\
\text { amputation }\end{array}$ \\
\hline
\end{tabular}




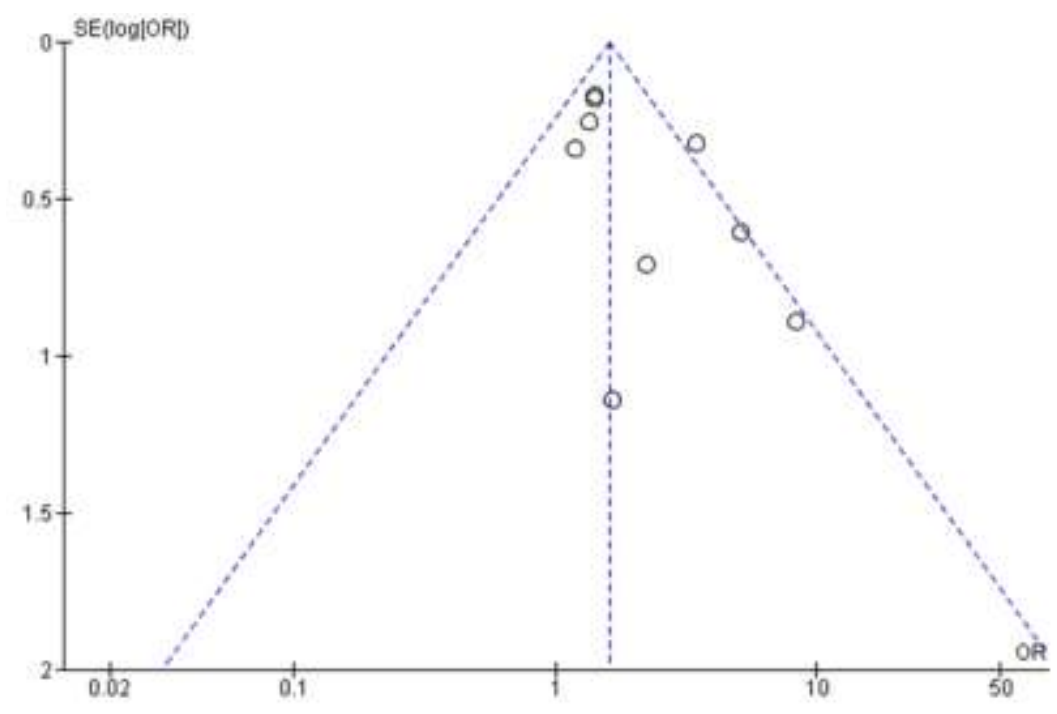

\section{Figure 8. Funnel plot for meta-analysis of gender relations with amputation of the lower limb in diabetic foot ulcers}

\section{Peripheral artery disease of lower limb amputation}

The results of a meta-analysis of 9 articles on peripheral artery disease with lower limb amputation in people with diabetes mellitus with foot ulcers showed that patients with diabetic foot ulcers with peripheral artery disease were 2.46 times more likely to have lower limb amputation than those without peripheral artery disease. The results of this study are consistent with study by Chaturvedi et al., (2001) and Pemayun et al., (2015) which showed that lower limb amputations increased significantly when accompanied by peripheral artery disease.

The results of this study are also supported by Markowitz et al., (2005) which states that PAP has the strongest effect on the occurrence of lower limb amputations and the risk is threefold. Aysertyildiz et al., (2018) shows that PAP has a significant role, especially in elderly patients with diabetic foot infection. Patients with these conditions should be immediately evaluated and treated to prevent PAP and infec- tion with microorganisms and ending limb loss.

Prompers et al., (2007) stated that the major amputation rate and mortality were found to be significantly higher in the PAP group ( $8 \%$ and $9 \%$, respectively) than in the non-PAP group ( $2 \%$ and $3 \%$, respectively). Research by Rastogi et al., (2017) stated that the presence of high ulcer rates, poor lower limb vascularization, PAP and infection are factors that increase the poor prognosis of wound healing and end up undergoing amputation, despite revascularization efforts.

Peripheral artery disease (PAP) results from atherosclerosis of the arteries of the lower extremities resulting in narrowing or occlusion of the arteries. The most severe form of PAP is called chronic ischemia which threatens the limbs and carries a significant risk of limb loss and cardiovascular death (Barnes et al., 2020). The onset of peripheral artery disease is gradual but progressive. It is often asymptomatic but has serious effects. Atherosclerosis is generally seen with increasing age in both adults and the elderly. In 
peripheral artery disease, there is a buildup of fatty deposits on the walls of the artery system. These fatty deposits, also known as atheroma, cause a decrease in the artery lumen. Decreased lumen causes stenosis and restricts blood flow and supply to the specific affected area (Welten et al., 2009). The reduced blood flow can slow wound healing and make the body less effective at fighting the virus. Thus, there is tissue damage or death (gangrene) and can spread into the bone. If the infection cannot be treated, then amputation is necessary to reduce the spread of tissue damage (Aiello et al., 2014).

\section{Hypertension on lower extremity amputation}

The results of a meta-analysis of 8 articles on hypertension with lower limb amputation in people with diabetes mellitus with leg ulcers showed that patients who had diabetic foot ulcers with hypertension were 1.05 times more likely to experience lower limb amputation than those with normal tension. The results of this study are consistent with research conducted by Resnick et al., (2004), Young et al., 2008 and Zubair et al (2012) which state that hypertension also contributes to the growth and development of chronic diabetes complications and is considered a risk factor for atherosclerosis.

These results are similar to those reported by Magalhães et al., (2011) which stated that amputated people had higher systolic blood pressure than non-amputated people $(\mathrm{p}<0.05)$ and showed increased arterial stiffness in subjects with lower limb amputations. These results support a stronger correlation between arterial stiffness and systolic blood pressure. Chronic elevations in blood pressure can accelerate hardening of the central arteries, thereby contributing to the rapid structural and functional changes in these artery walls.
Arterial stiffness is also associated with the development of PAP, which involves a gradual decrease in blood flow to one or more limbs due to atherosclerosis (O'Rourke and Nicholas, 2005).

Hypertension affects atherosclerosis, which increases peripheral ischemia. Diabetic patients have a high risk of developing atherosclerotic peripheral vascular disease, because of the presence of peripheral vascular disease, blood flow obstruction will occur which in turn will complicate healing. Ischemia of the diabetic foot causes gangrenous lesions. Limb ischemia has also been identified as a risk factor for amputation in patients with diabetic foot lesions (Nanwani et al., 2019).

According to Budiman-mak et al., (2016), hypertension is not the main influence of lower limb amputation in patients with diabetic foot ulcers. However, hypertension has a pervasive downstream effect on other risk factors for amputation such as PAP, neuropathy, and ischemia. The mechanism of its journey is that hypertension increases the pressure on the walls of blood vessels and accelerates the deposition of cholesterol plaque, resulting in stenosis and PAP.

\section{Gender to lower limb amputation}

The results of a meta-analysis of 9 articles on gender with lower limb amputation in people with diabetes mellitus with foot ulcers showed that patients who had diabetic foot ulcers were male, 1.60 times more likely to experience lower limb amputation than women. This is in line with Bruun et al., (2013), Al-Mahroos and Al-Roomi (2007), and López-de-Andrés et al., (2011) which state that lower limb amputation in diabetic ulcers is significantly higher in males than females.

Differences in the behavior of men and women are often used to explain this situation. Men often experience more 
physical burdens and social pressure than women, and this may be a reason for them to force them to feel healthy and strong. Women have a hormonal protective effect from estrogen. Hormonal factors can play a role because women (especially of reproductive age) may have additional neuroprotection afforded to them, due to better endothelial function in both the microvasculature and the microvasculature (Shin et al., 2017).

Rodrigues et al., (2016) stated that gender differences are caused by better wound care in women, because men are more often involved in strenuous physical work activities. Importantly, absence from wound care controls was higher among men. This problem causes the ulceration to take longer to heal.

Men were more likely to have several independent predictors for lower limb amputation, such as diabetic foot ulceration, cigarette use, $\mathrm{PAD}$, and peripheral neuropathy. Peripheral neuropathy may be a very important factor in sex differences in lower limb amputations. Sensory neuropathy is the most common type of neuropathy associated with diabetic foot ulceration, and men are almost twice as likely to have insensitive neuropathy as women and have more severe nerve conduction disorders. Insensitive neuropathy is determined in part by the length of the peripheral nerves (a function of height) because longer fibers are more susceptible to injury. The possibility of increasing sensory neuropathy in men is entirely due to the influence of height (Peek, 2010).

\section{AUTHOR CONTRIBUTION}

Anissa Eka Septiani is the main researcher who chooses topics, collects research data, formulates articles, and processes data. Setyo Sri Rahardjo helped formulate a framework for learning and discussion.
Hanung Prasetya formulated the background.

\section{CONFLICT OF INTEREST}

There is no conflict of interest in this study.

\section{FUNDING AND SPONSORSHIP}

This study is self-funded.

\section{ACKNOWLEDGEMENT}

The researcher thanks and appreciates the electronic databases of PubMed, Scopus, Google Scholar and Springer Link.

\section{REFERENCE}

Acar E, Kacira BK (2017). Predictors of lower extremity amputation and reamputation associated with the diabetic foot. J Foot Ankle Surg, 56(6): 1218-1222. https://doi.org/10.1053/j.jfas.2017.06.004.

Aiello A, Anichini R, Brocco E, Caravaggi C, Chiavetta A, Cioni R, et al. (2014). Treatment of peripheral arterial disease in diabetes: a consensus of the Italian Societies of Diabetes (SID, AMD), Radiology (SIRM) and Vascular Endovascular Surgery (SICVE). Nutr Metab Cardiovasc Dis. 24(4): 355-369. https://doi.org/10.1016/j.numecd.2013.12.007.

Al-Mahroos F, Al-Roomi K (2007). Diabetic neuropathy, foot ulceration, peripheral vascular disease and potential risk factors among patients with diabetes in Bahrain: a nationwide primary care diabetes clinic-based study. Ann Saudi Med, 27(1): 25-31. https://doi.org/10.5144/0256-4947.2007.25.

Yıldız PA, Özdil T, Dizbay M, Tunçcan OG, Hizel K (2018). Peripheral arterial disease increases the risk of multidrug-resistant bacteria and amputation in diabetic foot infections. Turk $\mathrm{J}$ 
Med Sci. 48(4): 845-850. https://doi.org/10.3906/sag-1803-217.

Barnes JA, Eid MA, Creager MA, Goodney PP (2020). Epidemiology and risk of amputation in patients with diabetes melitus and peripheral artery disease. Arterioscler Thromb Vasc Biol, 40(8): 1808-1817. doi:10.1161/atvbaha.120.314595 .

Beaney AJ, Nunney I, Gooday C, Dhatariya $\mathrm{K}$ (2016). Factors determining the risk of diabetes foot amputations - A retrospective analysis of a tertiary diabetes foot care service. Diabetes Res Clin Pract, 114: 69-74. doi:10.1016/j.diabres.2016.02.001.

Budiman-Mak E, Epstein N, Brennan M, Stuck R, Guihan M, Huo Z, Emanuele N, Sohn MW (2016). Systolic blood pressure variability and lower extremity amputation in a non-elderly population with diabetes. Diabetes Res Clin Pract, 114: 75-82. https://doi.org/10.1016/j.diabres.2016.01.010.

Bruun C, Siersma V, Guassora AD, Holstein $\mathrm{P}$, de Fine Olivarius N (2013). Amputations and foot ulcers in patients newly diagnosed with type 2 diabetes mellitus and observed for 19 years. The role of age, gender and co-morbidity. Diabet Med. 30(8): 964-972. https://doi.org/10.1111/dme.12196

Chaturvedi N, Stevens LK, Fuller JH, Lee ET, Lu M (2001). Risk factors, ethnic differences and mortality associated with lower-extremity gangrene and amputation in diabetes. The WHO Multinational Study of Vascular Disease in Diabetes. Diabetologia. 44(2): S65-S71. https://doi.org/10.1007/ploooo2941.

Jeon BJ, Choi HJ, Kang JS, Tak MS, Park ES (2016). Comparison of five systems of classification of diabetik foot ulcers and predictive factors for amputation. Int Wound J, 14(3): 537545. doi:10.1111/iwj.12642.

Krittiyawong S, Ngarmukos C, Benjasuratwong Y, Rawdaree P, Leelawatana R, Kosachunhanun N, et al. (2006). Thailand diabetes registry project: prevalence and risk factors associated with lower extremity amputation in Thai diabetiks. J Med Assoc Thai. 89(1): S43-S48.

López-de-Andrés A, Martínez-Huedo MA, Carrasco-Garrido P, Hernández-Barrera V, Gil-de-Miguel A, JiménezGarcía R (2011). Trends in lowerextremity amputations in people with and without diabetes in Spain, 20012008. Diabetes care, 34(7): 15701576. https://doi.org/10.2337/dc11-o077.

Magalhães $\mathrm{P}$, Capingana $\mathrm{DP}$, Silva $\mathrm{AB}$, Capunge IR, Gonçalves MA (2011). Arterial stiffness in lower limb amputees. Clin med insights Circ respir pulm Med. 5: 49-56. https://doi.org/10.4137/CCRPM.S7757.

Markowitz JS, Gutterman EM, Magee G, Margolis DJ (2006). Risk of amputation in patients with diabetic foot ulcers: a claims-based study. Wound Repair Regen. 14(1): 11-17. https://doi.org/10.1111/j.1743-6109.2005.0oo83.x.

Moon KC, Kim SB, Han SK, Jeong SH, Dhong ES (2019). Risk factors for major amputation in hospitalized diabetik patients with forefoot ulcers. Diabetes Res Clin Pract, 158, 107905. doi:10.1016/j.diabres.2019.107905

Nanwani B, Shankar P, Kumar R, Shaukat F (2019). Risk factors of diabetic foot amputation in Pakistani Type II Diabetes Individuals. Cureus, 11(6): e4795. https://doi.org/10.7759/cureus.4795 . 
O'Rourke MF, Nichols WW (2005). Aortic diameter, aortic stiffness, and wave reflection increase with age and isolated systolic hypertension. Hypertension. 45(4): 652-658. https://doi.org/10.1161/o1.HYP.0000153793.84859. b8.

Peek ME (2010). Gender differences in diabetes-related lower extremity amputations. Clin Orthop Relat Res, 469(7): 1951-1955. doi:10.1007/s11999-010-1735-4.

Pemayun TGD, Naibaho RM, Novitasari D, Amin N, Minuljo TT (2015). Risk factors for lower extremity amputation in patients with diabetik foot ulcers: a hospital-based case-control study. Diabetic Foot \& Ankle. 6(1): 29629. doi:10.3402/dfa.v6.29629.

Prompers L, Schaper N, Apelqvist J, Edmonds M, Jude E, Mauricio, et al. (2008). Prediction of outcome in individuals with diabetic foot ulcers: focus on the differences between individuals with and without peripheral arterial disease. The EURODIALE Study. Diabetologia, 51(5): 747-755. https://doi.org/10.1007/s00125-0080940-0.

Resnick HE, Carter EA, Sosenko JM, Henly SJ, Fabsitz RR, Ness FK, Welty TK, Lee ET, Howard BV, Strong Heart Study (2004). Incidence of lowerextremity amputation in American Indians: the Strong Heart Study. Diabetes care, 27(8): 1885-1891. https://doi.org/10.2337/diacare.27.8.1885.

Rodrigues BT, Vangaveti VN, Malabu UH (2016). Prevalence and risk factors for diabetic lower limb amputation: A clinic-based case control study. Diabetes Res Clin Pract. 1-7. https://doi.org/10.1155/2016/5941957.

Sayiner ZA, Can FI, Akarsu E (2019). Patients' clinical charecteristics and pre- dictors for diabetik foot amputation. Prim. Care Diabetes, 13(3): 247-251. doi:10.1016/j.pcd.2018.12.002

Shaw JE, Sicree RA, Zimmet PZ (2010). Global estimates of the prevalence of diabetes for 2010 and 2030. Diabetes Res. Clin. Pract. 87(1): 4-14. https://doi.org/10.1016/j.diabres.2009.10.00 7.

Shin JY, Roh SG, Sharaf B, Lee NH (2017). Risk of major limb amputation in diabetic foot ulcer and accompanying disease: A meta-analysis. Plast Reconstr Surg. 70(12): 1681-1688. https://doi.org/10.1016/j.bjps.2017.0 7.015

Vexels (2014). 5 Continent Wold Map Set. Retrieved from https://images.vexels.com/media/users/3/71348/raw/bd 9e68d11a591a9a61eac5f8do7fo385-5continent-world-map-set.jpg on November 2020

Welten GM, Schouten O, Chonchol M, Hoeks SE, Bax JJ, Van Domburg RT, Poldermans D (2009). Prognosis of patients with peripheral arterial disease. J Thorac Cardiovasc Surg. 50(1): 109-121. PMID: 19179996.

WHO (2020). Diagnosis and Management of Type 2 Diabetes (Heart-D). Geneva. Switzerland. Retrieved from https://www.who.int/publications/i/item/wh o-ucn-ncd-20.1 on May 2020.

Yesil S, Akinci B, Yener S, Bayraktar F, Karabay O, Havitcioglu H, Yapar N, Atabey A, et al. (2009). Predictors of amputation in diabetics with foot ulcer: Single center experience in a large Turkish cohort. Hormones, 8(4): 286-295. https://doi.org/10.14310horm.2002.1245.

Young BA, Lin E, Von Korff M, Simon G, Ciechanowski P, Ludman EJ, Everson-Stewart S, Kinder L, et al. (2008). Diabetes complications severity index 
Septiani et al./ Risk Factors for Lower Extremity Amputation

and risk of mortality, hospitalization, and healthcare utilization. Am J Manag Care, 14(1): 15-23. http://www.ncbi.nlm.nih.gov/pmc/articles/pmc3810070/.

Zubair M, Malik A, Ahmad J (2012). Incidence, risk factors for amputation among patients with diabetic foot ulcer in a North Indian tertiary care hospital. Foot (Edinb), 22(1): 24-30. https://doi.org/10.1016/j.foot.2011.o 9.003 . 